\title{
Gender Gap on the Job Market: Poland vs. Iran
}

\author{
Magdalena Simkowska-Gawron* \& Zahra Momenfar**
}

\begin{abstract}
Summary
Every year the number of Iranian students take the opportunity to complete their tertiary education in Poland increases - currently a third of them are women. Looking at the cross-cultural differences between Poland and Iran, it has become the aim of the authors to examine how they might affect educational attainment and employment opportunities of females in these respective countries. For that reason, they review relevant literature referring to a situation of women in terms of their educational and employment opportunities in Poland in Iran. They also look at gender-related stereotypes that might hinder professional opportunities of women in these two countries. As a complementing element, authors analyse the World Values Survey responses referring to stereotypical attitudes and their possible impact on gender discrimination at workplace in Poland and Iran.
\end{abstract}

Keywords: Women, Educational attainment, Female labour participation, Gender gap, Gender stereotypes.

JEL: M12, M14, J16

\section{INTRODUCTION}

Living in the era of globalisation marks intercultural and cross-national cooperation as essential for further growth - in a human and economic dimension. Seeking common denominators across cultures, and at the same time knowing the differences between them, may enhance exchange of knowledge, skills and talent. And through this - an increase of chances for successful collaborations in business, education, and other areas may be possible. Best example of such a cooperation is the collaboration between the authors of this paper - doctoral candidates at the cross-cultural management studies, one Polish and one Iranian. Even though they come from different cultural circles, in which they were brought up, gained education, and got their first employment experiences, they share their gender.

Being a woman in Poland and Iran may be associated with various social and economic factors and forces. However, gender-related behaviours and situations experienced by women on job markets in Poland and Iran, seem to be a natural way toward creating a starting point for future cross-cultural studies. It is worth remembering that the number of Iranian students at universities in Poland is constantly growing. With more Iranian students taking opportunity to complete their tertiary education in Poland every year (Polish Statistical Bureau, 2014, 2017a), and a third of them being females, it is essential to initiate a research on differences and similarities affecting such fields as education attainment and labour force participation in these two countries. Gender differences and inequalities stemming from these fields, are still alive and persistent. Even though they might be only of a stereotypical nature, they still determine such basic rights as access to education or employment opportunities of men and women, among others (Mandal, 2000). And these two elements directly translate into the level of economic and social participation, empowerment and overall success of representatives of the two genders (WEF, 2018).

The 21st century is characterised by fast development of technology and innovation, which is associated with unprecedented pace of social changes. In such circumstances, unique skills and talents play a crucial role in sustainable growth and every effort should be made to make it as

\footnotetext{
Faculty of Management, University of Warsaw, Poland, https://orcid.org/0000-0002-3998-5068, e-mail: msgawron@ wz.uw.edu.pl

** Ferdowsi University of Mashhad, Iran \& Faculty of Management, University of Warsaw, Poland, https://orcid.org/00000001-5639-5265, e-mail: z.momenfar@yahoo.com
} 
inclusive an environment as possible. Otherwise, all of the spheres, either public or private, business or education - would not only continue to waste talent but would also fail to follow the changes and modernisation that already commenced. Economists argue that the three assets, namely: fixed capital, human capital, and labour force have crucial and utmost impact effect on economic growth (World Economic Forum, 2018). They emphasise the relation between economic growth and gender inequality in basic human domains: health, education, employment, or remuneration. Some theorists refer to positive impact of gender inequality on economic growth (Barro \& Lee, 1994). While others (Galor \& Weil, 1996; Lagerlöf, 2003) proving negative influence - suggest that development in Europe (at least in economic and social terms) over the recent centuries has been connected with long-term changes in gender equality and development of egalitarian society. Clearly, the connection between gender (in)equality and economic growth has been one of the most debated concepts in recent times, regardless of the geographic latitude or socio-economic circumstances.

Recent economic analyses provide (WEF, 2018; Ferrant, 2015) that only an equal participation and contribution of women and men in world-changing processes will let the economies and societies prosper. Losing out on the skills, competitiveness, and innovative approach of half of the world's talent, has been reported as one of the major obstacles for sustainable growth and developmental opportunities the future may hold (WEF, 2018; Jaumotte, 2004). At the same time the effect is seen as mutual. Since lack of gender equality is affecting economic growth, economic progress also alters gender inequalities. Economic development is believed to impact gender inequalities by reducing access barriers in a job market for women, thus decreasing the amount of time spent at homecare and non-paid labour, and by changing institutional standards (van der Lippe \& van Dijk, 2002; Ferrant, 2015). It creates a joint relationship between economic growth and gender equality.

Multiple studies on women's employment show that economic development is an important factor in support of gender equality (WEF, 2018). It is often emphasised, however, that access to high quality education - at secondary level and beyond - is of utmost importance in the decisionmaking process of females whether to participate in the labour market or not. When combining paid and unpaid work, women - especially in developing countries - work more than men (that includes twice as much time on housework and other unpaid activities), with significantly less time for education, leisure, political participation, and self-care (Bielby \& Bielby, 1989; Fortin, 2005; Nagore Garcia, 2017; Vella, 1994; Verick, 2014).

The aim of this article, therefore, is twofold. First, we would like to review relevant literature referring to situation of women in terms of their educational and employment opportunities in Poland in Iran. Second, we would like to make an outlook on gender-related stereotypes that may hinder such opportunities. We will also analyse the opinions of Polish and Iranian respondents to the World Values Survey questions referring to stereotypical attitudes showing level of discrimination toward gender roles in society and at workplace.

Hence, the differences on the job market in Poland and Iran will be described in four main sections referring to potential gender disparities:

- Educational attainment

- Employment participation

- Gender pay gap

- Gender stereotypes

\section{COUNTRY COMPARISON - POLAND AND IRAN}

Poland and Iran are diverse countries in many dimensions - starting from the geographical location and cultural circles, up to social, demographic, or economic situation. There are also significant disparities in terms of women's participation in the public and economic spheres. In order to bring those differences closer to the readers, basic data comparison between Poland and Iran has been compiled. 
Iran has more than five times larger area and over twice as many inhabitants than Poland. Age structure of the two nations reveals that while Iran has a relatively young population with nearly a quarter of Iranian population below the age of 14 and less than $10 \%$ over 60 years old, Poland will have to face many of the challenges of an aging society with age rates reversed as compared to Iran $-14,8 \%$ of population below 14 years old, and $24 \%$ of Poles above the age of 60 years.

Women's representation in the public sphere looks slightly different in the two countries. Even though women constitute a near half of the population in both Iran and Poland, and on average are much better educated than men, their underrepresentation in the job market and political structures is significant, though more severe in Iran. In Iran less than 2 out of 10 women are active workforce, as compared to half of the female population in Poland. Only $16 \%$ of legislators and senior staff in Iran are women, with twice as high rate for women in Poland. The most acute example of gender disparity is, however, visible at the political decision-making level - only $3 \%$ of seats in Iranian parliament are occupied by women, while in Poland - a quarter of the available parliamentary posts are represented by women.

Table 1. Data comparison between Iran and Poland

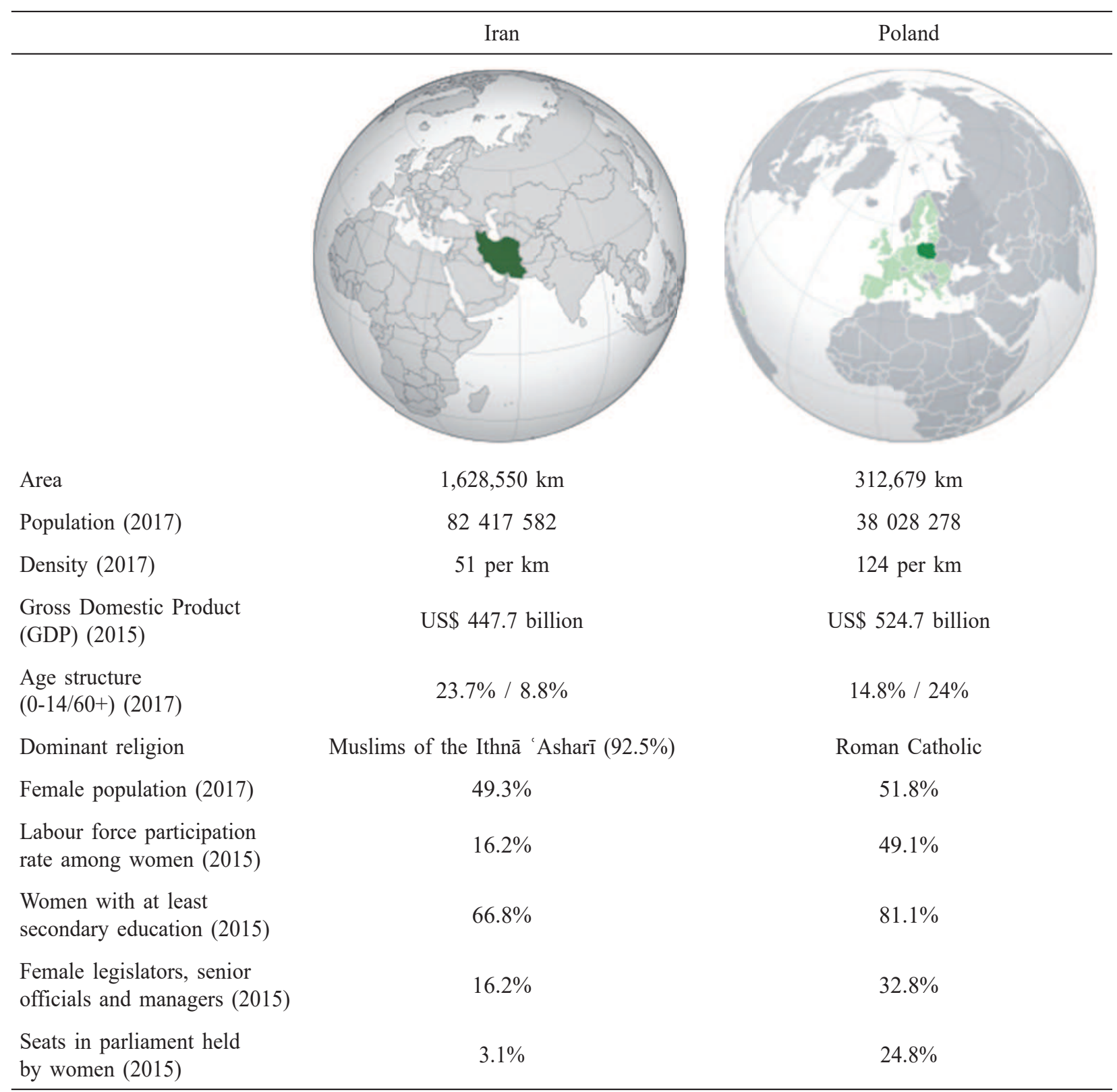




\section{EDUCATIONAL ATTAINMENT}

In the recent decades quick growth of educational investment and attainment among women has been observed. Women got to dominate men in secondary and tertiary education attainment in most of developed countries and among many of developing countries (UNESCO, 2018). There are more women among secondary education enrolled students and graduates, and that trend spreads toward the tertiary level rates of graduates. The widening gender gap in education in favour of women seems to be steady, with further potential growth in the future. Educational attainment datasets available at the Barro \& Lee's website ${ }^{1}$ confirm there were more women among university graduates in 54\% of the advanced economies in 2010. That number is even more remarkable taking into account that 60 years earlier men significantly outnumbered women in all of these economies (24 countries in total).

Multiple studies on women's employment show that professional career is an important factor in support of gender equality. In fact, in developing countries access to high quality education - at secondary level and beyond - is of crucial importance in the decision-making process of females whether to participate in the labour market or not (Bielby \& Bielby, 1989; Fortin, 2005; Nagore Garcia, 2017; Vella, 1994; Verick, 2014). It is not easy to relate directly labour market participation of women and socio-economic development of a particular territory. Yet, transformations of specific socio-economic issues such as access to quality education (understood as at least upper secondary), fertility rates, changes of social norms and others, might have had a key impact on the female labour participation rate (Verick, 2014). The more educated women are, the higher workforce participation rates. Therefore, as level of well-educated women increased worldwide, more women have undertaken paid occupations and the combination of the work and family roles in an adult life have become an ordinary situation. Despite a general character of the construct, these dimensions might take a different course for women and men - mainly due to normative expectations, social constraints, and biological conditions they face on a daily basis.

In Iran the number of women attending institutions of higher education has been steadily growing since 1989 (Kazemipour, 1999). Some argue (Shavarini, 2006) that women's college education is a waste of the nation's resources since the majority of college-educated women (approximately $75-80 \%$ ) do not get to participate in the labour market. To fully grab the complexity of that phenomenon it is necessary to get familiar with the Iranian higher education system. A high school diploma is earned after the completion of the third year. Out of the total eligible students, only $36 \%$ opt to continue to a fourth year on a college track by preparing for the national college entrance examination called "Konkur". That percentage of students continuing education is not equally distributed between the two genders - only $29 \%$ of men, compared to $42 \%$ of women, continue in the university stream. The final year of high school is an intense year of preparation to the National Entrance Examination. Konkur is an examination held annually in one of the summer months, and its participants attempt to get the results allowing them to attend the tuition-free public universities, seats at which are limited.

The results provide that merely $20 \%$ of the students taking the exam could count on seats at top public tertiary education institutions (others - if only can afford - may apply to courses at private universities in the country). In 2018 around $1 \mathrm{mln}$ individuals have registered for the exam, and female students constituted $59 \%$ of all the participants (Teheran News, 2018). Winning a seat at a public university is perceived in Iran as a privilege of a highly selected group, best of the best, who gain access to greater social and economic opportunities. Data from the beginning of the

The Barro \& Lee datasets provide educational attainment data for 146 countries in 5-year intervals from 1950 to 2010. It also provides information about the distribution of educational attainment of the adult population over age 15 and over age 25 by sex at seven levels of schooling, retrieved from: http://www.barrolee.com 
current millennium showed that out of 152000 students who passed Konkur in 2001, 60\% were women (Shavarini, 2005). The gender gap has continued to widen since then. In 2003, 62\% of those who passed the exam were women (Shavarini, 2006). Shortly after the results showing that women outnumber men in the national exam were released, not only these were the last results published officially afterwards, but also led to an implementation of gender quotas in public academia.

Over the following years Iranian parliament proceeded with laws limiting access to over 70 courses for female students. On one hand, among the banned courses there were such disciplines as engineering, technology, and mathematics-related. It was explained through the argument of waste of resources since majority of Iranian women with higher education would never join the workforce and pay back to the society (Winn, 2016). On the other hand, women were restricted from attending courses perceived as "Western" and "not in harmony with religious fundamentals" in Iran (Tait, 2012) - mainly in social sciences, psychology, law or management. Additional concerns were also expressed by national clerics who claimed that excessive educational attainment in these disciplines would have far-reaching social negative side effects to family life in Iran. These obstacles, nevertheless, have not discouraged Iranian women from pursuing university degree.

Iranian men, however, are not under pressure to gain higher education since college credentials do not enhance their abilities to improve their financial situation as it is in case of women. The Iranian labour market's need for skilled labour (i.e., a college-educated workforce) is limited, and what is more - men have priority over women in most areas of the employment market. For women, university education becomes one of a few viable means by which they can shape their future. Many Iranian women do not consider college a way through which they can acquire skills and knowledge (Shavarini, 2006). For Iranian women, university education is an experience of intangibles. It is giving them some sense of freedom beyond restrictive family control. It may also be seen as an asset, increasing woman's value in the marriage market (Rezai-Rashti \& Moghadam, 2011). Educational attainment is helping them to gain respect in the community, and of acquiring independence - also in financial terms, even though it does not necessarily mean entering a job market. All of these are rarely available to women in Iranian society (Shavarini, 2005). Nonetheless, as the research show (Salehi-Isfahani, 2001) in Iran educated mothers increase chances of better education of their children. One-year increase of mother's schooling increased her child's education - in rural areas by almost a year, and in urban areas - by nearly half a year. Thus, the role of development of human capital is another argument to take into account as an intangible advantage.

Slightly different situation appears in Poland. Education and skills are indispensable for finding a job. Primary education of men and women is at the same near $100 \%$ level, as it is obligatory at this stage. In terms of secondary education, 91\% of adults aged 25-64 have completed school at that level, which is a score higher by 17 percent points than the average for the OECD countries (OECD, 2017). Gender parity has been achieved here $-91 \%$ of eligible men and $92 \%$ of eligible women have successfully completed high-school education. Tertiary education enrolment and graduation rates are slightly shifted, though. In Poland, there is a visible trend among women striving to acquire knowledge and education, which is indicated by high rates of women among tertiary education graduates. There are almost twice as many female graduates than male among those completing tertiary education nowadays. Women dominate among most of the university disciplines, except IT and Engineering - perceived as typically male scientific domains (Polish Statistical Bureau, 2017).

The quality of education in Poland is perceived as high. And as more women graduate from tertiary education, that makes them more competitive on the job market - also at the European level (Dobosz, 2009). In Poland the recent testing of young students as a part of the Programme for International Student Assessment (PISA) conducted by OECD (2017) showed that the quality of the educational system in Poland on average is higher than for the OECD countries. The average Polish 
student got 504 points in reading literacy, mathematics and science. That gave a higher score than the OECD average which equalled 486 points. On average in Poland, girls outperformed boys by 4 points (average for OECD - girls scored 2 points more than boys).

Figure 1. Women among tertiary education graduates in Poland by discipline, academic year 2016/2017

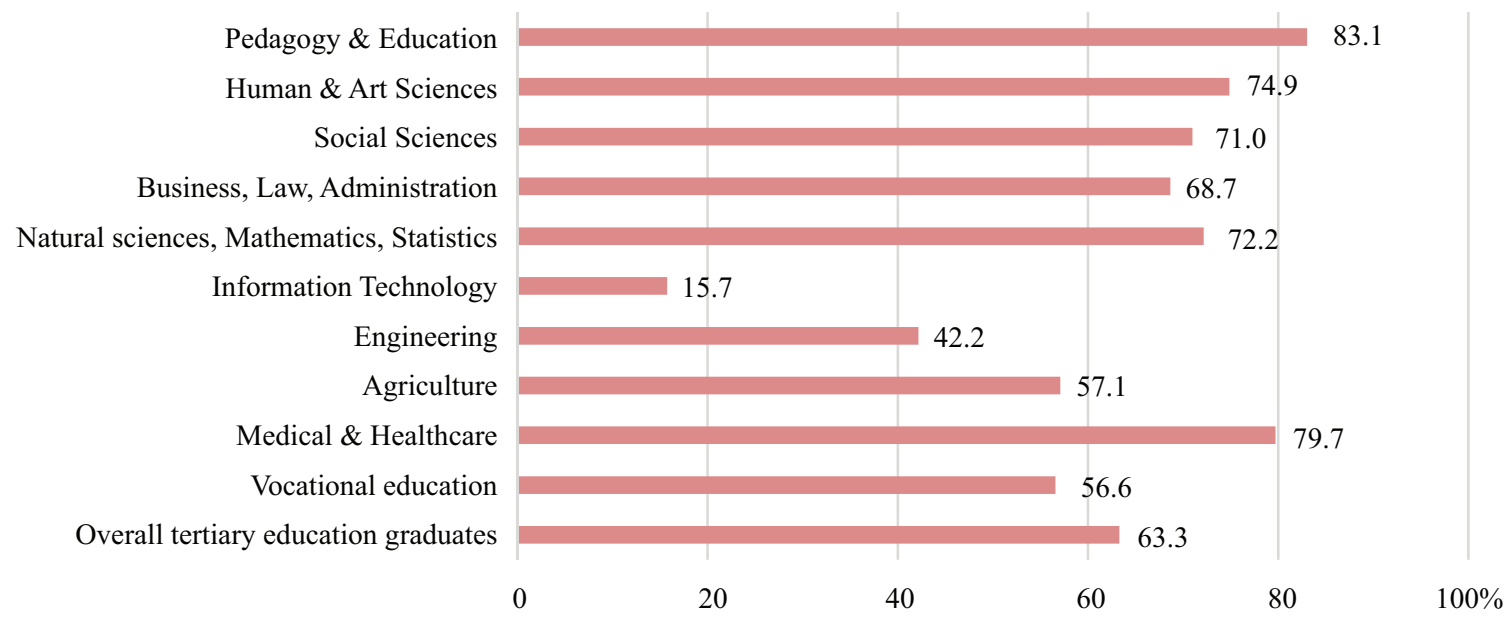

Source: Polish Statistical Bureau, 2017.

Education is one of the factors distinguishing level of unemployment in Poland. Higher levels of education significantly decrease the risk of unemployment among Polish women. What is significant, women with primary or basic vocational education are at largest risk of long-term unemployment or participation in shadow economy (Dobosz, 2009).

\section{EMPLOYMENT PARTICIPATION}

Gender differences are often discussed from the perspective of economic opportunities women and men might have or have taken advantage of. One of its elements is the labour market participation. Over the past decades ${ }^{1}$ number of women involved in a paid occupation has been increasing gradually around the world. The global labour participation rate in 1994 reached the ever-highest level of $51,5 \%$ of female population (age of 15 years and more), dropping later slightly to the level of 48,7\% in 2017. An analysis (Çagatay \& Ozler, 1995) looking for the connection between the work performed by women, their share in the labour market and long-term economic growth revealed that demographic and cultural issues determine significantly the degree of feminisation of the labour force. Female labour force participation is both an important driver and outcome of growth and development - not only in economic terms but also individual empowerment.

Women still work less hours in paid jobs than men over their whole lives, regardless of the level of education. Therefore, the return on the educational investment is much higher for men, who can fully benefit from the attainment of a university degree. Changes in that situation have been visible with female labour participation increasing substantially across the globe over the past decades. Women hold occupations adequate to their qualifications and education degree (Mulligan \& Rubinstein, 2008), and since 1980's there is a positive trend among highly educated women who are more likely to participate in the labour force. Since mid 1980's when enrolment and graduation

1 World Bank Data, International Labour Organization, ILOSTAT database. 
rates became a subject of socio-demographic and economic analyses, it has been observed there is a positive correlation between female labour force participation and the ratio of women to men in tertiary enrolment.

There are still some discussions on evidence regarding the causes of discrepancies in the labour market participation and return on investment in education, as well as what makes the shifts in these rates between women and men. Decreased gender discrimination in society might be seen as one of the reasons of the growing rates of female professional careers. Others claim (Ferrant, 2015; Fortin, 2005) that technology development has served as a time-saver in home chores performed by women, allowing them to devote more time to job outside of home. Other studies (Goldin \& Katz, 2002) provided evidence that common availability of oral contraceptives led to postponement of marriage plans and acts. There has been created a model (Galor \& Weil, 1996) considering link between fertility and growth. A lowered level of fertility rates is often an outcome of higher degree female education, which leads to reduced population growth. And looking further - has a positive effect on children's education and health. As a consequence, the quality of future human capital is enhanced. The human capital development resulted not only directly from women's educational attainment and their involvement in the labour market. It has been, though, an outcome of raising healthier and better educated offspring - an essential factor for further sustainable development (e.g.: Behrman, Foster, \& Rosenzweig, 1999).

The cause of workplace inequality comes from several sources. It may be manifested in such elements as appointment levels, amount of work, opportunity to get higher positions, access to role models and other actors that might contribute to job promotion (Haeri, 2013). It also results from having different level of human capital of men and women for instance in their choice between childbearing and work (Probert, 2005). Several studies in the gender diversity field conclude that there is a noticeable inequality between men and women in professional environments (Bedmar, Vaquero, \& Granados, 2017). In the workplace, men are more likely to be supported for jobs and advancement than women with the same conditions (Budworth \& Mann, 2010).

Figure 2. Changes in female labour force participation rate in Iran and in Poland (1990-2017)

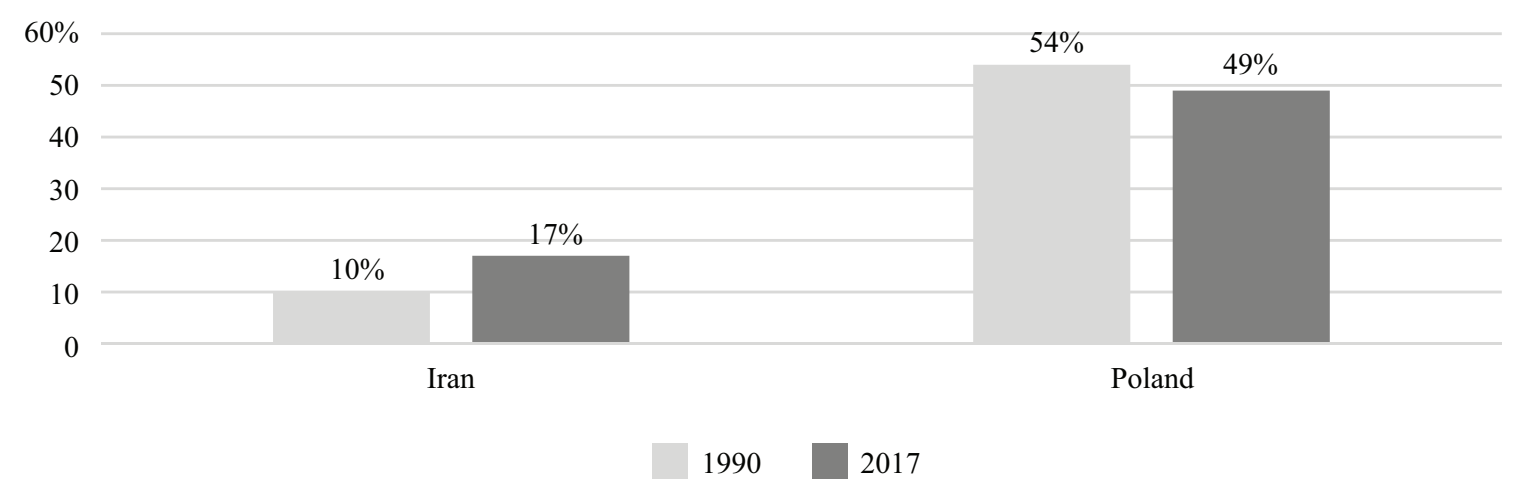

Source: World Bank, 2017.

According to World Bank data that factor in Iran showed 10\% rate of female employment in 1990 and 17\% in 2017, whereas in Poland 54\% and 49\% accordingly.

The pool of well-educated women in Iran is perceived as an "untapped source of growth and productivity gains" (International Monetary Fund, 2018). The report (IMF, 2018) points out that more Iranian women actively participating in a job market could significantly increase country's GDP, productivity, tax compliance, among others. Reduction of the gender pay gap by half can 
potentially enhance GDP by up to $26 \%$ (IMF, 2018). This could be possible through alleviating some of the obstacles, women experience in their daily life in Iran - laws restricting from joining the labour force, gender wage gap as the most oppressive sign of workplace discrimination, and lack of subsidies to childcare for lower income working mothers.

In Iran religious beliefs and ethnic biases significantly affect attitudes toward women's employment. In the constitution, labour law and civil law there are some restrictions on the free admission of women to certain occupations (Shavarini, 2006). Such attitudes and observations might threaten opportunities for women to enter the labour market and eventually upgrade their quality of life. Although there is a significant number of educated women in the Iranian labour market, the employment rate of women in Iran is very low. Only one in four women holding university degree has got a paid occupation, and among women with no higher education diploma that likelihood is even smaller (Burkova, 2017). In 2017 female labour force participation (FLFP) was around 17\%, which was a lower level than in countries with similar income per capita, including within the Middle East, and North Africa region (IMF, 2018).

Iran is perceived as a country that already closed its gender gap in terms of educational attainment, even though women have no access to certain university courses, or their access is limited by genderbased parities. Currently there have been very few new jobs created in Iranian private sector, which normally offered more job posts for women than the public sector. What is more, economic reliance on oil extraction and trade makes it even harder to shift that trend in employment opportunities for women. As it has been reported (IMF, 2018), even though there were almost six hundred thousand jobs created in Iran in 2017, most of which required low-skilled workers or agriculture workers, not matching both the aspirations and the skillset obtained by university-educated Iranian women. In such a situation frustration of highly-skilled women may increase. Especially that laws being implemented in Iran refer to the value of a woman as a housekeeper and recommend women to engage in such sorts of careers as midwifery and medical or teaching disciplines - as jobs that are best suited to them.

Eventually, laboratory science, electronic engineering, pharmacy, counselling, translations were pointed as jobs that do not match physically with the characteristics of fragile and weak women (Sedghi, 2007). Apart from social constraints in the job market participation and gender discrimination, women are more often employed in humanities and social sciences fields, traditionally associated with lower wages and lower status - therefore not necessarily preferred by men. In 2006 Iranian men were three times more likely to take up engineering courses at universities $(40 \%$ among men, $13 \%$ among women), while women more than twice more often chose subjects from such fields as arts, humanities, education, or health-related (12\% of men and $27 \%$ of women).

Entrepreneurship is seen as a great engine of the Iranian economy machine (Faghih, 2017). The average entrepreneur in Iran is male and young. Accordingly, 67\% of Iranian emerging entrepreneurs are seen as risk-takers. Women and men entrepreneurs are networking in the same way in the private sphere, but men are networking more than women in the public domain. Men enter entrepreneurship to increase social status and family income, while women choose entrepreneurship to fulfil their aspirations, self-satisfaction and needs for power (Jaimie, Sullivan, Chan Halbrendt, \& Qingbin, 1998; Hisrich, Peters, \& Shepherd, 2005). Financial needs and security needs are further priorities of any Iranian entrepreneurial woman.

In the civil law, the economic responsibility of the household to provide family livelihoods is by the husband's side. That is to say, the provision of alimony (food, clothing, housing) is normally borne by the husband, as well as the provision of education and training expenses for children. Also, in spousal relationships, the head of the family is male (Burkova, 2017). According to the maternal sacrament and the upbringing of the future generation and the management of the house - a part of the Iranian constitution, it is stated that the spiritual and material value of the role of women in the 
family and their work at home should be taken into consideration. It also holds a recommendation regarding hiring women - mainly in cultural, social and administrative jobs, including "conditions and the means of realizing social justice and social excellence".

Another example of a law attempting to regulate the role of a woman in Iran is a draft of the bill titled "The Comprehensive Population and Family Excellence Plan" (Human Rights Watch, 2015). The draft bill outlines incentive packages encouraging marriage and childbearing. It also includes discriminatory provisions such as creating a hierarchy for hiring in the public and private sectors based on gender and marital status of candidates, according to which businesses should focus on hiring employees in the given order: first - married men with children, then - married men without children, followed by women with children. There is, however, no mention about the female occupations in law and political activities. The low participation rate of women in political and managerial positions demonstrates that they do not belong in the Iranian decision and policy making process. Also, the role of women in the development process has not been recognised in Iran yet (Rostami-Povey, 2016).

With systemic transformations experienced within the recent three decades in Poland, the economic situation must have affected employment structure as well. In general, the impact of these changes has been perceived as more severe with regards to women than to men. Women more often were losing their jobs, remained unemployed in a long term, and experienced impoverishment due to gender discrimination in the job market (Gąciarz, 2011). Response of women to that state of events (namely unemployment, lack of development perspectives, poor work conditions) was entrepreneurship and establishment of own companies. In 2002 Polish female entrepreneurs were the third largest group in Europe $-37 \%$ percent of all entrepreneurs (mainly on the self-proprietorship basis), after Ireland and Iceland with more established business rules and traditions (World Bank, 2004).

Since then, in Poland the labour market has been improving gradually, and in the past five years for the prime-aged individuals (age 20-49) there has been observed a sharp fall of unemployment rate to a record low level of around 6-7\% for both genders (Magda, Kiełczewska, \& Brandt, 2018). The employment rate of men remains at a high level of around $75-80 \%$ in the last decade, compared to $60-70 \%$ of women actively participating in the Polish workforce. Interestingly enough, labour force participation among women in Poland depends hugely on the number of children and their marital status (Magda et al., 2018). On average, almost $80 \%$ of mothers of one or two children (below 18 years of age) are active in the job market, whereas it true for around $70 \%$ of mothers of three. This rate falls significantly to around $50 \%$ in case of mothers of four children. What is more, being a single mother lowers the likelihood of employment by 3-5\% percentage points. Being in a formal relationship without children increases the chance of employment by 10 percentage points when compared to single women without offspring, since many young women stay longer in education and as a consequence join the employment market relatively later than their married peers (Magda et al., 2018).

According to data on the employment structure in Poland (Kompa \& Witkowska, 2018), up to $30 \%$ of all job posts are in manufacturing, around $15 \%$ in retail and wholesale, up to $10 \%$ in education, and another $10 \%$ in healthcare and social services. The most feminised industries in Poland appear to be the following (Kompa \& Witkowska, 2018):

- Healthcare and social services - around $80 \%$ of women,

- Education - almost 80\% (in 2015),

- Financial intermediation - up to $70 \%$,

- HoReCa - up to $70 \%$.

The above are some of the least paid occupations in Polish economy. Taking into account that majority of women occupy lower and middle level in the professional ladder, that leads to even greater wage disparity between men and women. The biggest share of women (up to 70\%) is among 
the lower and medium level professionals, service workers, and clerks. Nonetheless, the biggest increase of women's participation in the recent years has been observed in the public sector (on the governmental level), as well as among senior officials and managers (by 10 percentage points) (Kompa \& Witkowska, 2018).

As compared to the EU average - Poland has one of the lowest female employment participation rates. The still strong stereotype of women responsible for child-bearing makes even more difficult for women to convince employers about their fitness and degree of flexibility required for employment. Another sign of discrimination is visible in the private sector dominated by male employees, who supposedly prefer to work with representatives of their own gender and consequently favour men in recruitment processes (Dobosz, 2009). The above is even more surprising that on average, Polish women have been perceived as more competitive in terms of their skills and educational preparedness - not only on a national level, but also on the European employment arena.

\section{THE PAY GAP}

Gender differences have been identified as induced by gaps in opportunities stemming from disparity in access to such assets as education, legal system, or financial services (Hakura, Hussain, Newial, Thakoor, \& Yang, 2016). Inequality resulting from gender differences may also emerge due to general lower representation of women in a job market, low wages (women are often thrown out of the official job market, supplying the shadow economy employment), and reduced political power with no impact on policy-making processes. Female workers' shift towards more specialised job, mainly due to the computerisation and reduction of middle-skill job for routine tasks, have either moved them up in the occupational ladder or pushed out of the labour market. And that have inevitably affected the income level of female workers.

A recent study (Ge, Isaac, \& Miller, 2018) of college degree graduates in USA showed that attending an elite school affects later-life outcomes - and that is true especially for women. Their advanced degree attainment was associated with increased earnings, and reduced likelihood of marriage. According to the researchers the declining marriage rate for those women was most likely due to them setting a higher bar for their potential life partners.

As female workplace segregation - either horizontal or vertical - continues to thrive, there might be no quick end to inequality in the area of paid work. Feminisation of particular industries or particular categories of work may therefore be perceived as a main reason for the widening gender pay gap (Kompa \& Witkowska, 2018). Simple comparisons of earnings, however, either within an industry between men and women or comparing productivity of men and women performing same or similar work, may not give measurable outcomes.

Gender discrimination may also take forms other than a pay gap between men and women. There might be discrimination in recruitment, occupational segregation, or human capital discrimination, when access to possible forms of training and development is not the same for both men and women, thus reducing human capital and its potential to grow (Kompa \& Witkowska, 2018). Among the key reasons of gender discrimination (Gąciarz, 2007), expressed also in a wage gap between men and women, there might be a perception of women as "high-risk" workers, who - as compared to "universal" men - would have to perform their maternal duties. This notion is very often strengthened by the stereotypical definition of a man as a family breadwinner. Another one is strong stereotype of typically feminine professions. That is seen as ability to work only in certain professional "feminised" branches offering low-paid occupations or observed through gender bias in a form of a "glass ceiling", or "sticky floor" to name just a few examples (Zuo \& Tang 2000).

In Islamic practice, women's work combines three areas - household, formal workforce, and shadow economy. According to the Islamic tradition strengthening family values and reproduction 
have priority over other occupations reserved for women. Recent governmental projects in Iran praise mothers and their effort put to childbearing and upbringing of children. Official communication promotes predominant female duties, highlighting "the importance of women as trainers of the Islamic community and [...] the role of motherhood and the image of pious and devout mothers. Biology became the prescribed destiny for all Iranian women" (Sedghi, 2007: 228).

Even though Iranian women hold such a high position in the society, they are primary victims of economic violence. No access to formal employment means substantial dependence on a partner or relatives, which translates to limited access to financial services, controlled access to basic health services, and exclusions from decision-making (Financial Tribune, 2017). Such an approach in Iran, forces women to search for paid employment outside the formal economic system, where no strict rules limiting women's access to work do not exist. Although the official reports talk about the formal employment of women at the level of 13-16\%, economists claim it is significantly underestimated (IMF, 2018). It simply does not include informal work and part-time employment, which might be even twice as high. According to Iranian statistics, women who are contributing to the home budget constitute $12 \%$ of the total number of households in Iran, there also women who in practice are sole breadwinners, for example, due to their husbands' addiction or absence, which are not reported in official statistics. Most of these families would not make their end meet and would slip under poverty line if not for that income from informal employment. These jobs are mainly in the services industry or private-own small enterprises, imposing on these women huge threat to health and safety, and offering remuneration below the standard pay and no benefits (IMF, 2018).

IMF (2018) reports the shadow economy in Iran constituted a third of the Iran's GDP in 2016. Access to employment is described by the vice president for women and family affairs, Shahindokht Molaverdi as a major demand of Iranian women reporting through the website of the department. And still, World Economic Forum's 2018 Global Gender Gap ranked Iran 142nd among 149 countries, providing that only seven other countries are doing worse on the gender equality agenda. Although Iran can boast about closing its gender gap in education, it may backslide on wage equality, labour force participation rates, professional workers market access (WEF, 2018).

In Poland, educational attainment of women has resulted in their increased participation in the job market in the recent years. And even though they earn gradually more in some occupations, earnings of men in general have been higher than those of women (Dobosz, 2009). Econometric analysis of data ${ }^{1}$ (Roszkowska \& Majchrowska, 2014) showed that although women on average earned around a dozen percent less than men, there is no reason to reject the hypothesis about equality of education return between men and women. Authors of the analysis argue that the lower average wages of women in Poland result from several issues:

- women more often than men work in lower-paid occupations, but which provide greater employment stability (differences in the employment structure);

- employment breaks related to motherhood and childbearing - after their maternal leaves, women return to their "old" salaries, while the rest of the company received increases in the meantime;

- more frequent need to combine professional life with home and family duties, which often reduces women's/ mothers' availability, possibility of foreign travels, or willingness to take managerial positions (giving higher earnings, though requiring greater time commitment, often unpredictable).

For Poland, wage discrimination of women is one of the lowest in Europe (7.2\% in 2018 compared to the average of $16.2 \%$ in the EU). The gender pay gap in Poland is often explained by differences

\footnotetext{
1 Analysis based on average monthly gross wages and salaries from reports submitted by employers employing at least 10 employees in 2004-2010 in Poland.
} 
in the amount of paid work performed by men and women and that through their lifetime women work less, with long-term breaks - mainly due to pregnancy and maternity leave. As a consequence of some lack of flexibility from in that respect, women less often request pay rise and express higher readiness to low-paid work in exchange for stability and predictability of working hours. It is also claimed (Kompa \& Witkowska, 2018) that women accept lower pay due to possible risk of losing the job or not getting the job offer. In such a situation self-valuation and self-esteem of women might be one of the factors as well, originating from the Christian-catholic tradition referring to shared values, specific cultural norms and traditional roles, dominant in Poland and accepted by majority of the Polish society Kopycińska \& Kryńska, 2016).

The conducted analyses (Kopycińska \& Kryńska, 2016) show that Polish female employees normally occupy industries that traditionally offer lower wages. Highest earnings are offered in such branches as mining, energy, water supply, finance and banking, governmental administration. In the two latter sectors, in 2014 women earned $36.7 \%$ and $16 \%$ less than men, respectively. Disproportions are visible at particular levels of education. Nonetheless, the smallest income disparity is observed between men and women with tertiary education (and the gap here is steadily narrowing), while the largest among employees with lowest education degrees. In most of the traditionally feminised sectors, average salaries fell below the average earnings for the whole Polish economy. Consequently, wage discrimination originating from industry segregation is present in Poland. It is also visible that the gender pay gap is shrinking for most of professions except technology specialists and associate professionals.

\section{GENDER STEREOTYPES}

The word "stereotype" comes from the Greek phrase "stereos" (meaning: solid, hard) and "typos" (meaning: imprint, pattern). Stereotypes are therefore defined patterns that allow for easier information processing. Gender is one of simplifications - it is the basis of effortless, automatic categorisation. Thus, one cannot escape from activating the prototype of a woman or man. An intercultural research conducted in 28 countries (Williams \& Best, 1982) provided explanation to the existence of gender stereotypes in all of the cultures under study. The masculinity-femininity stereotypes have a complex structure (Deaux \& Lewis, 1984, which consists of information about physical and mental characteristics, as well as social and professional roles.

Together with the stereotype of a woman, there is activated a set of "feminine" associations:

- physical features containing the image of a delicate, graceful lady called the "weak sex" and "beautiful sex" (except apart from the prototype of "a sweet fragile woman" there is also a prototype of "a hoyden");

- mental traits related mainly to emotionality, warmth, sensitivity, caring, ability to sacrifice, submission;

- social roles such as caring for children and running a home;

- professional roles related to care and help (nurse, kindergarten teacher, assistant).

- Along with the stereotype of a man, there is activated a set of "male" associations:

- physical features containing the image of a well-built, "as hard as steel" man referred to as "strong sex" and "ugly sex";

- mental traits related to self-confidence, risk-taking, independence, aggressiveness, competence, or rationality (to be a winner, to win a competition, not to be like a woman/ girl) (Brannon, 2002);

- social roles such as keeping the family (being a breadwinner), taking care of finances, protecting the family from any threats;

- professional roles related to decision making in typically masculine areas: politics, military, inventiveness. 
The activation of these stereotypes is associated with diverse expectations regarding the behaviour of representatives of the two genderss. The prototypical woman cares for a fulfilling family life, beauty, sacrifices herself for children. Professional career is the second priority in a woman's life at its best. For a prototypical man, professional work is of the utmost importance. It is the family that is held in the background.

Gender stereotypes concern the features that differentiate one gender from another. For example, normally when referring to a gender stereotype, one would make no additional reference to the eye color or hair color, nonetheless there might be included information about the height. Still, the stereotypical information would suggest that men are taller than women. The symptoms of stereotypes can be overt (Thornton, Alwin, \& Camburn, 1983) - when one openly criticises the son-in-law who decided to quit his job to become a "homemaker" or a "work-at-home dad" - or covert when one supports his decision, considering it a rational choice, feeling at the same time uncomfortable for some reason. The stereotype of a woman consists of a prototype and information about the extent of its permissible transformations (Wieczorkowska-Wierzbińska, 2018).

Tests measuring school performance or ability to further education attainment show that gender differences are evident. Typically, on average, men score higher in mathematical tests while results in verbal skills testing are higher among women (Wieczorkowska-Nejtardt, 1997). What is worth emphasizing, however, the variance of scores among men is higher than among women - regardless of the discipline (Hedges \& Nowell, 1995; Machin \& Pekkarinen, 2008).

And it is true in terms of the central/mean value because on average men are taller than women. Nonetheless, it significantly distorts reality as it gives an impression that there is no intra-group diversity (variance) - suggesting that all women are shorter than all the men, causing short men and tall women feel somehow "inadequate", not fitting the standard/ stereotype. A similar distortion might be possible in terms of intellectual features. It is a fact that men prevail among people exceptionally talented mathematically. However, this does not mean that there are no women among that talented group. Yet, men also prevail among people who lack mathematical abilities, and that would untrue to claim that there are no women lacking that talent (Wieczorkowska \& Siarkiewicz, 2006). However, the variance in the group of women is much smaller than in the group of men. Achievement tests measuring school performance of student show there are gender differences. Typically, on average, men score higher in mathematical tests, while women's scores in verbal skills testing are greater (Wieczorkowska-Nejtardt, 1997; Król, 2002). Even though, regardless of subjects, the scores variance among men is higher than among women (Hedges Nowell, 1995; Machin \& Pekkarinen, 2008).

Likewise, gender stereotypes affect the attribution of success - the success of a woman is explained by her beauty, luck, high motivation, or other situational attributes. Man's success is associated with his fitness and personal abilities (Mandal, 2000; Deaux \& Emswiller, 1974). The discriminating influence of gender stereotypes was shown in classical studies (Goldberg, 1968) in which students rated significantly higher articles in various fields: law, linguistics, art history, architecture, dietetics, and teaching when they were signed by the author named "John" than when the name of the author "Jane" pointed a female author. This discriminatory gender stereotype could be distributed in different ways in different countries.

In Iran, like in other cultural circles, gender stereotypes and gender-specific socialisation practices impact individuals' viewpoints, thinking, judgments, self-concepts, and social behaviour (Poya, 1999). Such stereotypes represent men as active and independent, while women are portrayed as subordinate to and dependent on men. This gender inequality is reflected in less decision-making opportunities and agency for women compared with men (Sedghi, 2007). Women are socialised to care for others but are often considered too emotional and less capable to handle difficult and challenging situations. Men, by contrast, are portrayed to possess wisdom and sound judgment. 
To better understand the position of the women in Iran is worth to mention one of the Muslim feminist frameworks, which highlight the supposedly superior role of women in Iranian society (Shavarini, 2005). According to that framework it is capitalist and communist systems that exploit women as cheap labour. Western modernity has brought about sexual exploitation, alienation, and the depersonalisation of women, unlike the Muslim agenda. In the view of that framework, Islam is a socio-political and socio-economic system that does not take advantage of women. On the contrary - according to that framework - Islam honours, respects, and empowers women. For example, women are encouraged to work and are not obligated to share their income with either their family or their community. Women are in fact given the right to charge their husbands an entitlement (nafaqa) for nursing their own babies. It is the Western world that marks the veil as a symbol of women's bondage in a religiously legitimised patriarchal world (Bauer, 1985; Betteridge, 1983; Ramazani, 2001) and represents the seclusion, gender segregation, modesty, subordination. For Muslim feminists the veil liberates and protects women from the sexual harassment that permeates Western societies (Afshar, 1995). The major drawback of this framework is that it focuses on ideological issues rather than material and practical concerns of women's status in Iranian society, as that looks different in the real day-to-day life (Poya, 1999).

In Islamic tradition the attitude toward religion and spiritual issues among women is believed to be higher than among men. Therefore, men tend to be seen and more materialistic than women. There are many differences between the innate and the innocent men and women accordingly, it is natural that they should not be socially expected to behave in the same way that is why their gender differences in the preparation of duties and responsibilities from the beginning of childhood to young ages should be taken into consideration (Bauer, 1985). According to that belief - competitive works are recommended for boys, and due to the emotional and physical power of girls and women, they should learn home-based principles. Putting side by side the Iranian culture between two complex and interlocking traditions - that one has its roots in ancient Persia, the other in Islam - could be helpful to understanding Iranian culture. Cultural values dominate the structure, organisation and behaviours as they are deeply rooted in religious and philosophical beliefs.

International comparisons conducted at the European level indicate that even though Poles are not more conservative in terms of gender roles than other Eastern European countries, gender stereotypes in Poland seem to be still alive (Szelewa, 2011). In Poland, the stereotype of the "Polish Mother" has been in force for years. It consisted of such features as diligence, readiness for sacrifice, conviction about being irreplaceable in performing household duties, a certain level of multifunctionality in realizing these tasks and taking care of the family at the same time. The cultural characteristics of the "Polish Mother" syndrome - heroic and capable of bearing any burden, grew directly out of the Polish history. When the absent husbands died in the struggles for their homeland or they were imprisoned, women were engaged in running family farms or firms, they took care of ensuring the continuity of the Polish culture, language, and customs. The patriotic upbringing of children was a guarantee to maintain the national identity.

In the poem "To the Polish Mother", in which Adam Mickiewicz appeals that the mother's ultimate duty is to prepare her son for the role of a warrior for the Homeland. And the analogy to the fate of the Mary Mother of God is evident. The Marian Cult, which was typical to Catholicism in Poland, also had a positive influence on the position of Polish women. In the period of real socialism, related to the shortage economy, one can observe a "household matriarchy". For it was women who then had a sense of agency, as without their sacrifice (e.g. through gaining food in a kilometre-long-queues, or culinary ingenuity in a situation of total limitation of produce), the family would not have a chance to survive. It was women who made (and continue to make) most of the household purchasing decisions, but they pay for this "power" with exhaustion. Women manage their family households, giving men the power to decide on important issues which take place in the public sphere in return. 
Another element of gender relations in the era of socialism was the "gentry-knightly contract" (Walczewska, 1992), according to which a woman encourages a man to fight for his homeland, she sacrifices herself taking over his duties in the due time, and later also dresses his wounds incurred during the fight. But in the times of peace a knight is a gentleman who adores his lady, and is a gallant social activist who handles carnation flowers on the occasion of the Women's Day. The functioning of that contract created the illusion that women in Poland have always been surrounded with extraordinary reverence, respect, and admiration, so all movements fighting for equality have been unnecessary. The socialist gender equality - expressed in the common slogan "women on tractors" - in the long run has increased the number of women in typically men's professions in which they performed very well. Yet, the times have changed and among younger generations, brought up in a democratic system, more egalitarian attitudes are observable - both at home and in the professional environment (Baranowska, 2007). Modern women in Poland with their thrive to knowledge attainment associated with entrepreneurial approach are perceived as innovators "seeking a remedy for the social discrimination inflicted on them" (Gąciarz, 2009). This approach stands in opposition to the old stereotypical notion of women as passive, obedient and dependable, compared to men who are natural leaders, decisive, competitive, and successful.

It is still comfortable to use these stereotypes in the public sphere in order to control the environment, and setting traditional roles to men as managers and to women as those who execute orders. However, contemporary Polish women empowered by good quality education, commitment, ability for adaptation and their readiness to innovate, are creating potential for business development. This constitutes a promising foundation for further changes in social status of women not only in Poland but also anywhere in globalised economy where they would like to work and live.

\section{Gender stereotypes in the world values survey - Poland and Iran}

To illustrate the possible gender-related stereotypes in Poland and Iran, we have conducted an analysis of responses to selected statements from the World Values Survey, Wave 5 (Inglehart et al., 2007). We looked at the statements that refer to level of gender discrimination and other possible cross-cultural disparities in that respect.

\section{Participants}

Our analyses were conducted with regards to responses provided by 3667 people -2667 individuals from Iran and 1000 from Poland. Gender and age structure of the two cohorts reflected population composition of the two countries:

- in Iran: $49.9 \%$ women $/ 50.1 \%$ men (ages $16-90 ; \mathrm{M}=32.69 ; \mathrm{SD}=12,769 ;$ median $=30$ years);

- in Poland 52.4\% women $/ 47.6 \%$ men (ages 18-92; $\mathrm{M}=45.21 ; \mathrm{SD}=17.845 ;$ median $=44$ years).

\section{Materials and Procedure}

In the analyses we focused on the following statements from the World Values Surveys (Wave 5), which all combined allowed further to measure the DV: "level of discrimination":

- When jobs are at scarce men have more right to a job than women

- Men make better business executives than women

- Men make better political leaders than women

- University education is more important for boys

In case of the first statement ("When jobs are at scarce men have more right to a job than women") responses were given with a three-point Likert-like scale $(1=$ disagree, 2 = neither agree nor disagree, 3 = agree). In case of the three remaining statements - responses were recorded with a four-point Likert-like scale $(1=$ strongly disagree, $2=$ disagree, $3=$ agree, $4=$ strongly agree $)$. 
The items formed one factor in a factor analysis explaining $57.6 \%$ of total variance. Cronbach's alpha for the scale equaled $\alpha=.749$. Factor scores were computed and used in the further analyses. The higher the score, the higher level of discrimination observed.

\section{RESULTS}

We used a regression analysis in order to determine which of the individual variables are best at predicting respondents' level of gender discrimination. We regressed level of discrimination (high values equal higher level of gender discrimination) on gender $(1=$ male, $2=$ female $)$ and country (364 $=$ Iran, $616=$ Poland) and interaction of the two variables, as well as educational attainment ( $1=$ below primary, $5=$ tertiary), job status $(1=$ employed, $2=$ not employed $)$, and marital status $(1=$ in a relationship, $2=$ not in a relationship). The results can be seen in Table 2 and in Figure 3.

Table 2. Regression analysis of the level of gender discrimination.

\begin{tabular}{lcccc}
\hline & $\mathrm{B}$ & Beta & $t$ & $p$ \\
\hline Constant & 4.458 & & 59.129 & .000 \\
gender & -.299 & -.231 & -13.880 & .000 \\
country & -.003 & -.463 & -29.479 & .000 \\
interaction gender*country & .038 & .058 & 3.906 & .000 \\
age & .002 & .039 & 2.044 & .041 \\
education & -.037 & -.164 & -10.537 & .000 \\
employment status & .075 & .054 & 2.804 & .005 \\
relationship status & -.020 & -.015 & -.960 & .337 \\
\hline $\mathrm{R}^{2}=0,285$, adjusted $\mathrm{R}^{2}=0,283$ & & & & \\
\hline
\end{tabular}

For the analysed sample - gender, country and education level proved to be strongest predictors and showed negative relationship to the level of gender discrimination. Women $(\beta=-0.231$, $p<.000)$, respondents in Poland $(\beta=-0.463, p<.000)$, and well-educated respondents $(\beta=-0.164$, $p<.000)$ in general tend to display lower lever of gender discrimination. Age $(\beta=0.039, p<.041)$ and employment status $(B=0.054, p<.005)$ are related with level of gender discrimination. In their case higher age and lack of employment of respondents predicted higher level of gender discrimination. At the same time relationship status of respondents proved to be insignificant in predicting level of gender discrimination they presented $(p<.337)$.

Based on the conducted regression analysis, women display lower level of gender discrimination than men. Together, respondents in Poland present more egalitarian attitude than those in Iran. At the same time, differences between men and women in terms of the presented levels of gender discrimination are larger in Iran than in Poland (for illustration, please see Figure 3).

The primacy of men and their right to rule the job market is more visible in Iran, both among men and women. In Poland, respondents were more reluctant to prefer men in the race for scarce jobs, nonetheless there were still (almost a third of all responses) many accepting male dominance in that respect (Figure 5). 
Figure 3. Interaction of gender and country on the level of gender discrimination

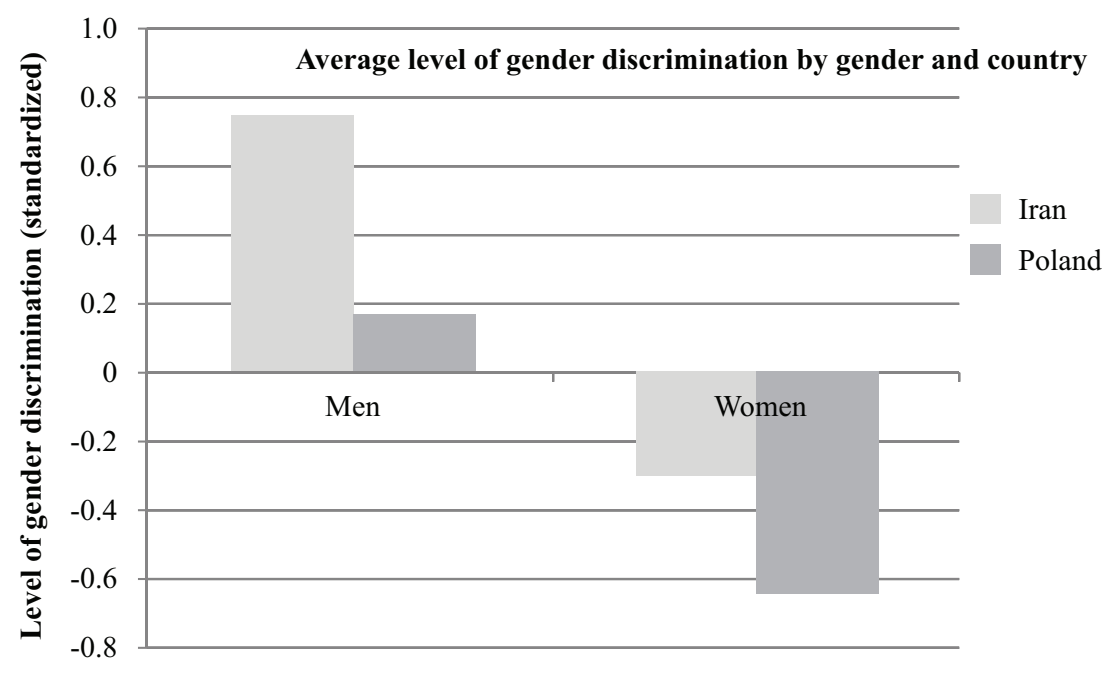

Figure 4. Responses to a statement "When jobs are at scarce men have more right to a job than women"

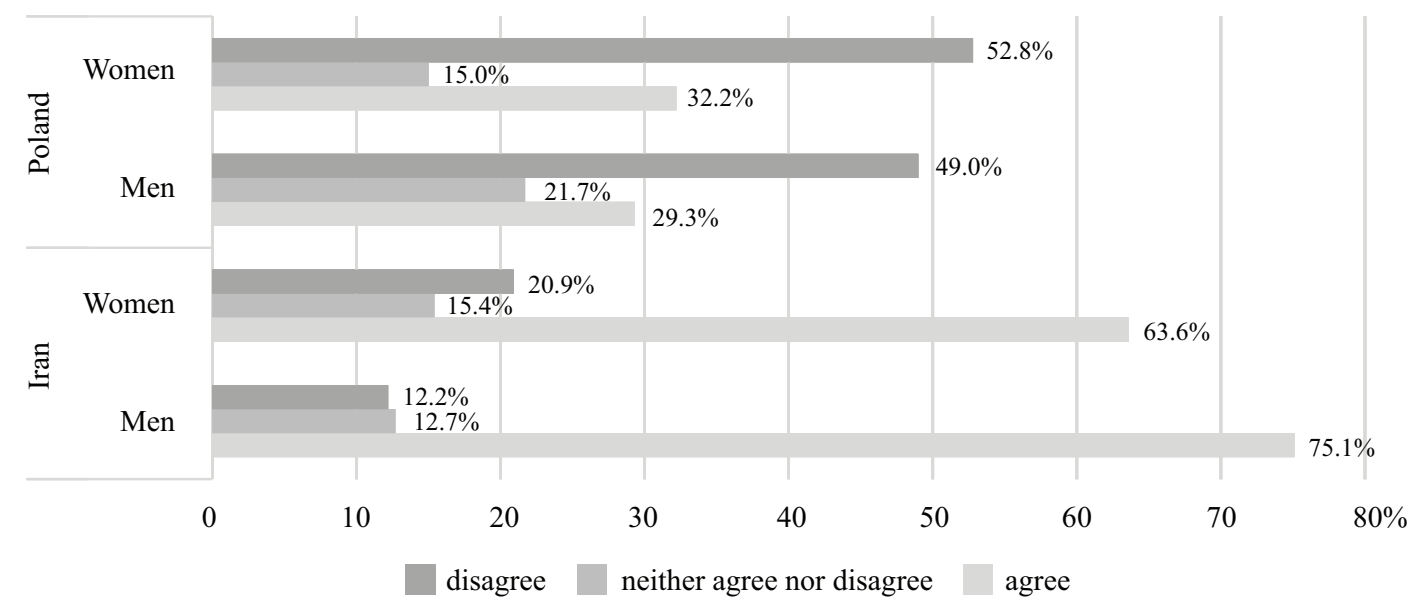

Figure 5. Responses to a statement "Men make better business executives than women"

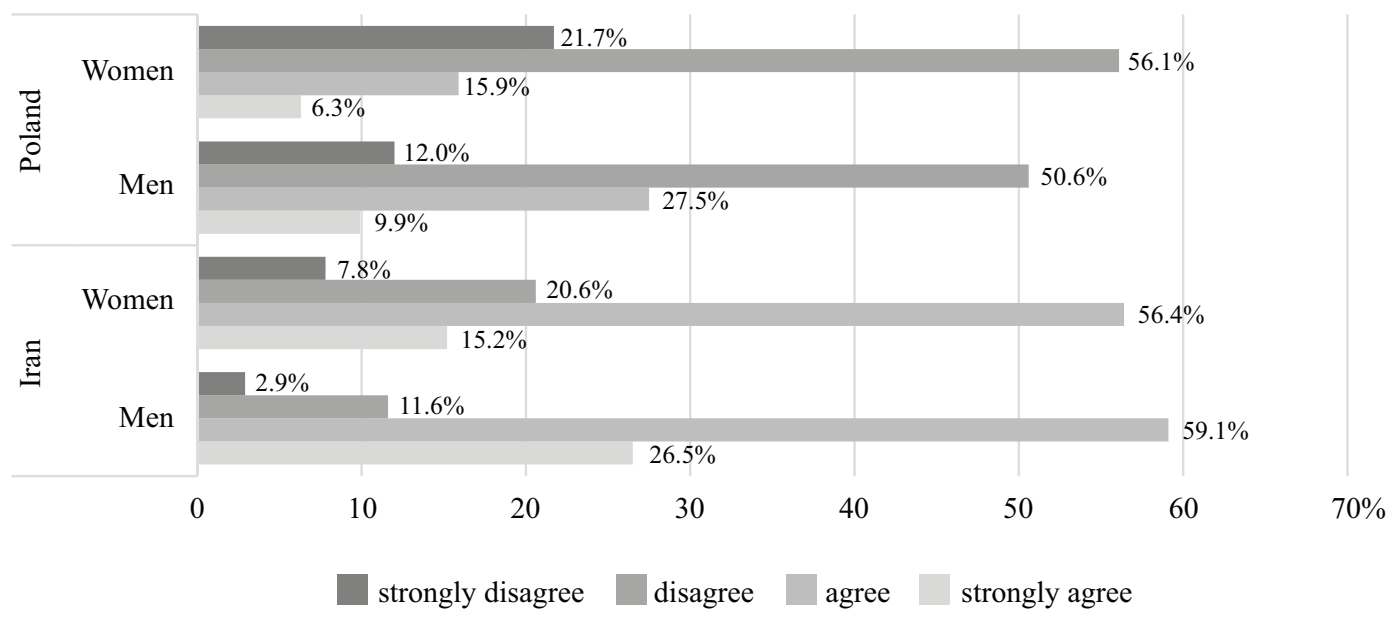


Men in Iran are perceived as more suitable for the role of business executives - fitting the stereotype of a male manager and female subordinate fulfilling orders. In Poland sympathy for the gender segregation is visible more among men, among whom one in three respondents agreed representatives of their own gender would be better at top positions.

Figure 6. Responses to a statement "Men make better political leaders than women"

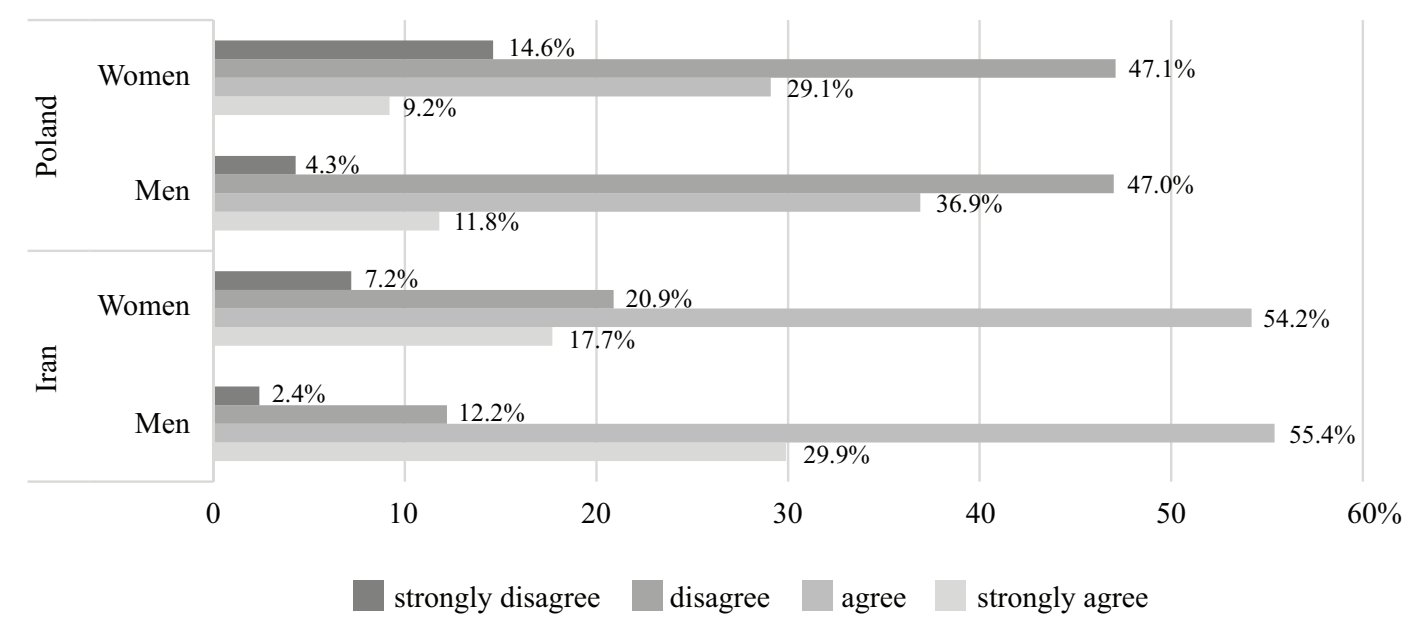

Again, Iranian respondents were more favourable toward the prospect of male political leaders, which somehow is visible currently in the Iranian society, where barely $3 \%$ of parliamentary seats are held by women, and only one in eight managers is female. Responses among Polish respondents were more or less divided by half. Showing that there is growing acceptance for women in political decision-making roles.

Figure 7. Responses to a statement "University education is more important for boys"

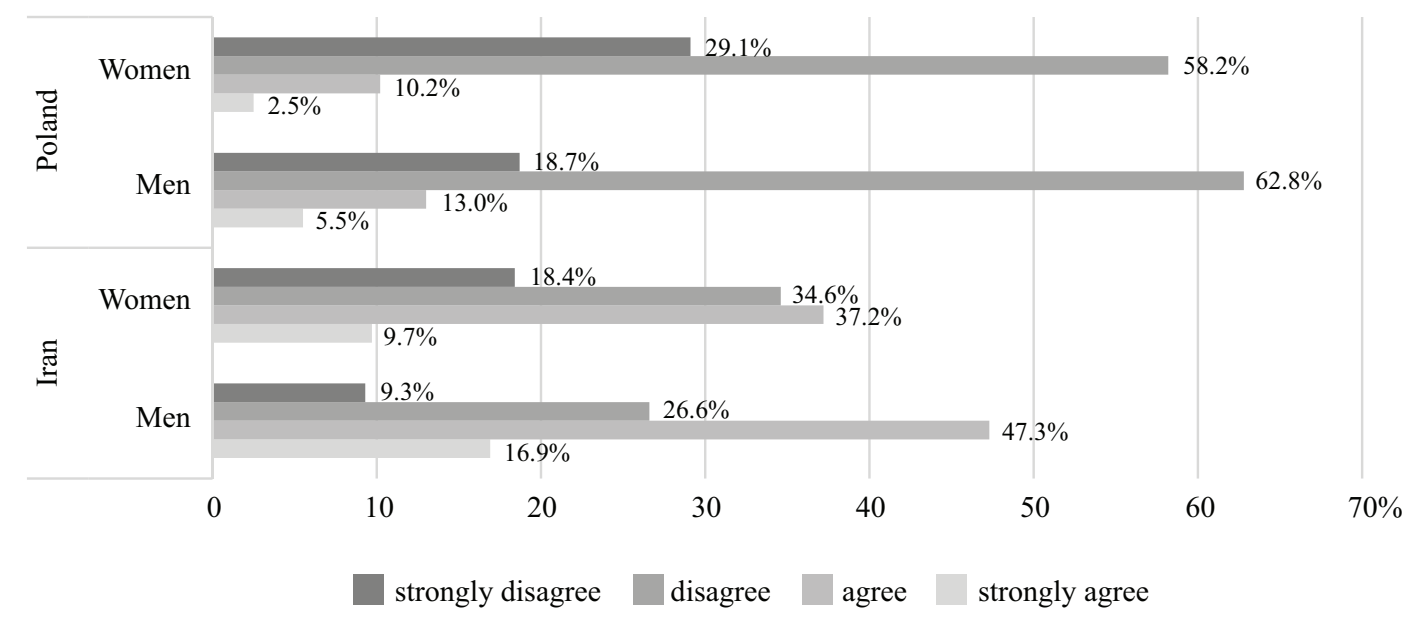

Perceiving university education as more important for male students shows a higher level of discrimination among respondents who might regard women's education as a waste of resources since their role would be to care for home of children. In Poland there is visible disagreement toward such inequality. Over $80 \%$ of both female and male respondents expressed their egalitarian attitude toward roles of men and women in the society. 


\section{SUMMARY}

As historically proved, gender differences in the work and family dimensions have been present invariably for the whole past centuries. The gender lens reveals social constraints, employment segregation, and pay gap imposed on women, and reinforced by men and women through their daily lives. These find simple rationalisations for discriminatory practices in the public sphere, workplace and at the privacy of their homes. Inequalities cut across all dimensions of sustainable development - social, economic and environmental and pose obstacles to all goals. Inequalities exist both within and between countries (Imbierowicz, 2012). Women often lack access to decent work opportunities and face occupational segregation and gender wage gaps. They are underrepresented in political, economic decision-making processes and academic career.

Poland and Iran differ in terms of their gender gaps - and in terms of the outcomes stemming from that disparity in many areas. In both countries the majority of university students are female. However, the majority of the workforce in Iran is formed by males, which is not the case in Poland where gender gap in the workforce is relatively low. Iran managed to close the education gap, while in Poland education gap is in favour of women. Still, there might be different motivations behind the university education enrolment among Polish and Iranian women on an individual level. Nonetheless, through admission to and graduation from university women from both countries seek to be more employable, and to improve their earning potential and social status (Rezai-Rashti \& Moghadam, 2011). In many cases these advantages of higher education attainment would be associated with delayed marriage and a lower rate of reproduction on one hand, and with better employment and enhanced social and gender awareness on the other.

Women's life choices are believed to be dictated by their personal perception of the traditional family model (Fortin, 2005). Attitudes concerning females' education, marriage, maternity or employment are developing over years, and are influenced by their families. Among these specific features are education and religiosity of parents, social sentiments or barriers created by public institutions. And only later they are offset with person's motivations, priorities and personal ambitions.

Through the literature review authors aimed at presenting the situation of women in Iran and Poland in terms of their educational and employment opportunities. In both cases the origins and consequences of observable gender disparities might be different and strongly depend on cultural issues governing these societies. Social constraints imposed by religion play a crucial role in how strong the gender-related stereotypes in these societies are. Stereotypes significantly hinder women's opportunities in Poland and Iran, provide rationale for discriminatory behaviours and attitudes, and allow for maintaining gender gaps in most areas of public and private spheres.

The analysis of the reviewed literature and the World Value Survey responses allow to establish that women's professional prospects in Poland and Iran might be affected by both cultural factors and to some extent - level of gender discrimination. It is, however crucial to understand that in ethical and social terms lower level of gender disparity stimulates and strengthens basic human rights. In economic terms, closing of the gender gap through enhanced access to education, advances the quantity and quality of human capital fuelled by the potential of women (Siegel, 2005). Such a situation, as a consequence, increases social and economic development by improving productivity and bringing in progressive benefits (Financial Tribune, 2017).

\section{Literature}

Afshar, H. (1995). Women and the Politics of Fundamentalism in Iran, in H. Afshar (ed.), Women and Politics in the Third World. London: Routledge, 121-141.

Algan, Y., \& Cahuc, P. (2004). Job Protection and Family Policies: The Macho Hypothesis. Discussion Paper IZA DP No. 1192, Eurequa-Université de Paris I. Retrieved from: https://hal-sciencespo.archives-ouvertes. fr/hal-01065504 
Baranowska, A. (2007). Views and preferences regarding economic model of the family, in: Kotowska, I. E., et. al. (eds.) Aktywność zawodowa i edukacyjna a obowiazki rodzinne $w$ Polsce $w$ świetle badań empirycznych [Professional and educational activity and family obligations in Poland in the light of empirical research]. Instytut Badań nad Gospodarką Rynkową, Warsaw, 404-422.

Barro, R., \& Lee, J. (1994). Sources of Economic Growth. Carnegie-Rochester Conference Series on Public Policy, 40, 1-46.

Baturo, A., \& Gray, J. (2018). When do family ties matter? the duration of female suffrage and Women's path to high political office. Political Research Quarterly, 71(3), 695-709.

Bauer, J. (1985). Sexuality and the Moral „Construction” of Women in an Islamic Society. Anthropological Quarterly, 58(3), 120-129.

Behrman, J., Foster, A., Rosenzweig, M., \& Vashishtha, P. (1999). Women's Schooling, Home Teaching, and Economic Growth. Journal of Political Economy, 107(4), 682-714.

Betteridge, A. (1983). To Veil or not to veil: A Matter of Protest or policy, in Nashat, G. (ed.) Women and Revolution in Iran. Boulder, CO: Westwind.

Bielby, D., \& Bielby, W. (1984). Work Commitment, Sex-Role Attitudes, and Women's Employment. American Sociological Review, 49(2), 234-247.

Bielby, W., \& Bielby, D. (1989). Family Ties: Balancing Commitments to Work and Family in Dual Earner Households. American Sociological Review, 54(5), 776-789.

Blackden, C. M., \& Bhanu, C. (1999). Gender, Growth, and Poverty Reduction: Special Program of Assistance for Africa. Status Report on Poverty in Sub-Saharan Africa. Working Papers, World Bank - Technical Papers.

Brannon, E. M. (2002). The development of ordinal numerical knowledge in infancy. Cognition, 83(3), 223-240.

Budworth, M., \& Mann, S. (2010). Becoming a leader: the challenge of modesty for women. Journal of Management Development, 29(2), 177-186.

Burkova, R. (2017). It's a men's club. Discrimination Against Women in Iran's Job Market. Human Rights Watch. Retrieved from: https://www.hrw.org/report/2017/05/25/its-mens-club/discrimination-against-womenirans-job-market

Cagatay, N., \& Ozler, S. (1995). Feminisation of the labour force: The effects of long-term development and structural adjustment. World Development, 23(11), 1883-1894.

Chiao, J. Y., Bowman, N. E., \& Gill, H. (2008). The political gender gap: Gender bias in facial inferences that predict voting behavior. PLOS ONE, 3(10), e3666.

Davis, N. J., \& Robinson, R.V. (1991). Men's and Women's Consciousness of Gender Inequality - Austria, West Germany, Great Britain, and the United States. Sociologic Review, 56(1), 72-84.

Deaux, K., \& Emswiller, T. (1974). Explanations of successful performance on sex-linked tasks: What is skill for the male is luck for the female. Journal of Personality and Social Psychology, 29, 80-85.

Deaux, K., \& Lewis, L. L. (1984). Structure of gender stereotypes: Interrelationships among components and gender label. Journal of Personality and Social Psychology, 46(5), 991-1004.

Dobosz, K. (2009). Situation of Women on Labour Market in Poland. Economics \& Competition Policy. Labour Market in EU and in the World, Katedra Mikroekonomii Uniwersytetu Szczecińskiego, 5(14), 154-118.

Ferrant, G. (2015). How Do Gender Inequalities Hinder Development? Cross-Country Evidence. Annals of Economics and Statistics. 117-118.

Financial Tribune. (2017, July 3). Women overshadowed in Iranian Labour Market. Retrieved from: https:// financialtribune.com/articles/domestic-economy/67601/women-overshadowed-in-iranian-labor-market

Fortin, N. (2005). Gender role attitudes and the labour-market outcomes of women across OECD countries. Oxford Review of Economic Policy, 2.1(3), 416-438.

Gąciarz, B. (2011). Women in the workplace in Poland. International Journal of Sociology, 41(3), 68-94.

Galor, O. \& Weil, D.N, (1996). The gender gap, fertility, and growth. American Economic Review, American Economic Association, 86(3), 374-387.

Ge, S., Isaac, E., \& Miller, A. (2018, November). Elite Schools and Opting-In: Effects of College Selectivity on Career and Family Outcomes, NBER Working Paper No. 25315.

Goldberg, P. A. (1968). Are women prejudiced against women? Transactions, 5, 28-30.

Goldin, C., \& Katz, L.F. (2002). The power of the pill: Oral contraceptives and women's career and marriage decisions. Journal of Political Economy, 110(4), 730-770.

Haeri, S. (2013). No end in sight: politics, paradox and gender policies in Iran. Boston University Law Review, 93(3), 1049-1062.

Hakura, D., Hussain, M., Newial, M., Thakoor, V., \& Yang, F. (2016). Inequality, Gender Gaps and Economic Growth: Comparative Evidence for Sub-Saharan Africa. IMF working paper, WP/16/11.

Hedges, L. V., \& Nowell, A. (1995). Sex differences in mental test scores, variability, and numbers of highscoring individuals. Science, 269(5220), 41-45. 
Hellerstein, J. K., Neumark D., \& Troske, K.R. (2002). Market forces and sex discrimination. The Journal of Human Resources, 37(2), 353-80.

Hisrich, R. D., Peters, M. P., \& Shepherd, D. A. (2005). Entrepreneurship (6th ed.). New York: McGraw-Hill/Irwin.

Human Rights Watch (2015). World Report 2015: Iran, Events of 2014. Retreived from: https://www.hrw.org/ world-report/2015/country-chapters/iran

Imbierowicz, A. (2012) Matka Polka w defensywie? Przemiany mitu i jego wpływ na sytuację kobiet w polskim społeczeństwie. Ogrody Nauk i Sztuk, 2, 430-442. Retrieved from: http://bazhum.muzhp.pl/media// files/Ogrody_Nauk_i_Sztuk/Ogrody_Nauk_i_Sztuk-r2012 t2/Ogrody_Nauk_i_Sztuk-r2012-t2-s430-442/Ogrody_Nauk_i_Sztuk-r2012-t2-s430-442.pdf

Inglehart, R., Haerpfer, C., Moreno, A. et al. (eds.). (2014). World Values Survey: Round Five-Country-Pooled Datafile, Version: www.worldvaluessurvey.org/WVSDocumentationWV5.jsp

International Monetary Fund. (2018). Islamic Republic of Iran: Selected Issues. IMF Country Report No. 18/94.

Jaimie, S., Sullivan, P., Chan Halbrendt, C., \& Qingbin, W. (1998). An Exploratory Study of How Rural Female Entrepreneurs View Success. University of Vermont Publication.

Jaumotte, F. (2004). Labour Force Participation of Women: Empirical Evidence on the Role of Policy and Other Determinants in OECD Countries. OECD Economic Studies, 2003(2), 51-108.

Kazemipour, S. (1999). A pattern in determining the socio-economic status of people and measuring social mobility based on a case study in Tehran. Journal of Social Sciences Letter, 14(14), 139-172.

Kiser, A. I. T. (2015). Workplace and leadership perceptions between men and women. Gender in Management, 30(8), 598-612.

Kompa, K., \& Witkowska, D. (2018). Factors affecting men's and women's earnings in Poland. Economic Research-Ekonomska Istraživanja, 31(1), 252-269.

Kopycińska, D., \& Kryńska, E. (2016). Wage Inequalities between Men and Women in Poland - a Justified Differentiation or Accepted Wage Discrimination of Women? Economics and Sociology, 9(4), 222-242.

Król, D. (2002). Wybrane uwarunkowania, korelaty i konsekwencje stereotypów ptci. Nieopublikowana rozprawa doktorska. Faculty of Psychology, University of Warsaw. Supervisor: prof. dr hab. Grażyna Wieczorkowska.

Lagerlöf, N. (2003). Gender Equality and Long-Run Growth. Journal of Economic Growth, 8(4), 403-426.

Llorent-Bedmar, V., Llorent-Vaquero, M., \& Navarro-Granados, M. (2017). Towards gender equality in Moroccan universities: Female university teachers from a gender perspective. Women's Studies International Forum, 64, 34-40.

Machin, S., \& Pekkarinen, T. (2008). Global sex differences in test score variability. Science, 322(5906), 1331-1332.

Magda, I., Kiełczewska, A., \& Brandt, N. (2018, March). The "Family 500+" child allowance and female labour supply in Poland. Institute for Structural Research. IBS working paper 01/2018.

Mandal, E. (2000). Podmiotowe i interpersonalne konsekwencje stereotypów związanych z płcią. Prace Naukowe Uniwersytetu Ślaskiego w Katowicach, 0208-6336(1856), 237-268.

Moghadam, F. (2009). Undercounting Women's Work in Iran. Iranian Studies, 42(1), 81-95.

Mulligan, C., \& Rubinstein, Y. (2008). Selection, Investment, and Women's Relative Wages over Time. The Quarterly Journal of Economics, 123(3), 1061-1110.

Nagore Garcia, A. 2017. Gender Differences in Unemployment Dynamics and Initial Wages over the Business Cycle. LISER, 2017, Working Papers.

OECD (2017). Better Life Index: Poland. Retrieved from: http://www.oecdbetterlifeindex.org/countries/poland/

Polish Statistical Bureau (2017). Szkolnictwo wyższe w roku akademickim 2016/2017. Retrieved from: http:// stat.gov.pl/obszary-tematyczne/edukacja/edukacja/szkolnictwo-wyzsze-w-roku-akademickim-20172018-danewstepne, $8,5 . \mathrm{html}$

Polish Statistical Bureau. (2014). Szkoły wyższe i ich finanse w 2014 roku-aneks studenci i kierunki studiów. Retrieved from: http://stat.gov.pl/obszary-tematyczne/edukacja/

Polish Statistical Bureau. (2017a). Szkoły wyższe i ich finanse w 2017 roku-aneks studenci i kierunki studiów. Retrieved from: http://stat.gov.pl/obszary-tematyczne/edukacja/

Poya, M. (1999). Women, work and Islamism: ideology and resistance in Iran. New York and London: Zed Books.

Probert, B. (2005). 'I just couldn't fit it in': Gender and unequal outcomes in academic careers. Gender, Work \& Organisation, 12(1), 50-72.

Ramazani, R. (ed.). (2001). Iran at the Crossroads. New York: Palgrave Macmillan.

Reskin, B. R., McBrier, D. B. \& Kmec, J. A. (1999). The Determinants and Consequences of Workplace Sex and Race Composition. Annual Review of Sociology, 25(1), 335-361.

Rezai-Rashti, G., \& Moghadam, V. (2011). Women and higher education in Iran: What are the implications for employment and the "marriage market"? International Review of Education, 57(3/4), 419-441. 
Rostami-Povey, E. (2016). Women's Education and Employment in Iran, in S. Takhar (ed.) Gender and Race Matter: Global Perspectives on Being a Woman. Advances in Gender Research, 21, 63-83.

Roszkowska, S., \& Majchrowska, A. (2014). Premia z wykształcenia i doświadczenia zawodowego według płci w Polsce. Instytut Ekonomiczny Warszawa, Materiały $i$ Studia, 302.

Rueden, C. von, Alami, S., Kaplan, H., \& Gurven, M. (2018). Sex differences in political leadership in an egalitarian society. Evolution and Human Behavior, 39(4), 402-411.

Salehi-Isfahani, D. (2005). Human resources in Iran: potentials and challenges. Iranian Studies, 38(1), 117-147.

Sedghi, H. (2007). Women and Politics in Iran: Veiling, Unveiling, and Reveiling. Cambridge University Press: Cambridge. Retrieved from: https://www.sssup.it/UploadDocs/14639_7_R_Women_and_Politics_in_Iran_ Veiling_Unveiling_and_Reveiling_Hamideh_Sedghi.pdf

Shavarini, M. K. (2006). The Paradox of Higher Education in the Lives of Iranian Women. International Journal of Middle East Studies, 38(2), 189-211.

Shavarini, M. K. (2005). The feminisation of Iranian higher education. Review of Education, 51, 329-347.

Siegel, E. (2005). The Gender gap and Growth: Measures, Models and the Unexplained. University of Copenhagen, 1-19.

Siemieńska, R. (1996). Gendered perceptions: women in the labour market in Poland. Women's History Review, $5(4), 553-566$.

Szelewa, D. (2011). The policy on gender equality in Poland. Policy Department C: Citizens' Rights and Constitutional Affairs. European Parliament.

Tait, R. (2012, August 20). Anger as Iran bans women from universities. The Telegraph. Retrieved from: https:// www.telegraph.co.uk/news/worldnews/middleeast/iran/9487761/Anger-as-Iran-bans-women-from-universities. html

Teheran Times (2018, June 30). Fierce competition: Iran's university entrance exam held. Retrieved from: https:// www.tehrantimes.com/news/424879/Fierce-competition-Iran-s-university-entrance-exam-held

Thornton, A., Alwin, D.F., \& Camburn, D. (1983). Causes and consequences of sex-role attitudes and attitude change. American Sociological Review, 48(2), 211-227.

UNESCO (2018). Education: Percentage of female graduates by level of tertiary education. Retrieved from: http://data.uis.unesco.org

United Nations (2017). Population age structure in 2017 report. Retrieved from http://data.un.org

van der Lippe, T., \& van Dijk, L. (2002). Comparative Research on Women's Employment. Annual Review of Sociology, 28(1), 221-241.

Vella, F. (1994). Gender Roles and Human Capital Investment: The Relationship between Traditional Attitudes and Female Labour Market Performance. Economica, 61(242), 191-211.

Verick, S. (2014). Female labour force participation in developing countries. IZA World of Labour 2014: 87. Retrieved from: https://wol.iza.org/articles/female-labor-force-participation-in-developing-countries/long

Walczewska S. (ed.). (1992). Głos maja kobiety. Teksty feministyczne. Fundacja Kobieca eFKa, Kraków.

Wieczorkowska-Nejtardt, G. (1997). Czy kobiety czują się gorsze od mężczyzn w matematyce? in: Siemieńska, R. (ed.) Portrety kobiet i mężczyzn w środkach masowego przekazu oraz podręcznikach szkolnych. Warszawa: Scholar.

Wieczorkowska-Wierzbińska, G. (2018). Zarzadzanie ludźmi - pytania i odpowiedzi. Warszawa: Wydawnictwa Naukowe WZUW.

Williams, J. E., \& Best, D. L. (1982). Measuring sex stereotypes: a thirty-nation study. Newbury Park, CA: Sage Publications.

Winn, M. K. (2016). Women in Higher Education in Iran: How the Islamic Revolution Contributed to an Increase in Female Enrolment. Global Tides, 10(10).

World Bank. (2004). Gender and economic opportunities in Poland: has transition left women behind? Report no. 29205. Poverty Reduction and Economic Management Unit, Europe and Central Asia Region, Washington, DC: World Bank.

World Economic Forum (2018). Global Gender Gap Report 2018. Retrieved from: http://www3.weforum.org/ docs/WEF_GGGR_2018.pdf

Wysokie Obcasy. (2018, September). Polka Stulecia. Plebiscyt "Wysokich Obcasów” na sto lat polskiej niepodlegtości. Retrieved from: http://www.wysokieobcasy.pl/wysokie-obcasy/7,166192,23867864,plebisc yt-czytelniczek-wybierz-kobiete-stulecia-uzasadnij.html

Zuo, J., \& Tang, S. (2000). Breadwinner Status and Gender Ideologies of Men and Women regarding Family Roles. Sociological Perspectives, 43(1), 29-43. 